\title{
Richard Smith Coxe: Law and Politics in a Maturing Republic \\ By Bruce A. Bendler
}

DOI: https://doi.org/10.14713/njs.v8i1.263

Richard Smith Coxe was the descendant of a prominent Burlington, New Jersey, family. He followed in the footsteps of his father, William Coxe, by affiliating with the Federalist Party until its demise after the War of 1812. After manifesting an interest in New Jersey politics early in his career, Coxe left his home state, and its political life, relocating to Washington, DC, where he became a prominent attorney. In the nation's capital, he specialized in matters of maritime and international law. For a time, he worked closely with fellow New Jerseyan and Secretary of the Navy Samuel Southard. Despite his new focus on a legal career, Coxe remained, to a lesser degree, politically active, supporting the Whig Party, especially Henry Clay and William Henry Harrison. Although his political views were based on Federalist, then Whig, principles, Coxe's legal career led him, at times, to take exception to those principles. For example, while not overtly supporting war with Mexico in 1846, unlike many Whigs, he saw the claims of clients who had suffered losses because of political and social turbulence in Mexico as justification for more forceful action against that nation.

In 1822, Richard Smith Coxe left his hometown of Burlington, New Jersey, to practice law in Washington, DC. The son of a prominent New Jersey Federalist, William Coxe, Richard Smith Coxe himself faced unfavorable political prospects in his home state with the demise of the Federalist Party. Coxe decided that pursuing a career in the nation's capital might offer greater opportunities. Even though unable to seek elective office in the District of Columbia, Coxe remained politically active, at first offering advice about New Jersey presidential politics and, as the Second Party System coalesced, affiliating himself with the Whig Party and its 
principles. Though his career became more focused on law than politics, Coxe based his actions on those Whig principles. Even when taking exception to party "orthodoxy," he justified those exceptions with Whig rhetoric.

Over time, Coxe's interest in New Jersey politics waned. In 1824, he sought to play a role in the presidential contest in his home state, but as his career in the nation's capital advanced, Coxe focused his interest on national politics, particularly on Henry Clay and the emergent opposition to Andrew Jackson. Coxe's career thus diverged from those of his contemporaries. For example, another young Federalist, Garret Wall, threw his support to Jackson after the Federalists' demise and, in time, won election as one of New Jersey's United States senators. Coxe, on the other hand, chose a career path that drew him away from the raucous political life of Jacksonian New Jersey.

Coxe's career choice further diverged from those of his peers. He became less focused on political matters as he built his legal practice in the nation's capital. Unlike contemporaries such as Wall and Theodore Frelinghuysen, he left state politics behind to build his law practice in Washington. He thus largely left behind a political career to pursue a legal one, focusing on multinational cases that held implications for the role of the young American republic in the international arena. Even so, his choice enabled him to remain politically connected and, to an extent, active. Such a choice also required that Coxe put his clients' concerns, or his own judgment, ahead of political issues if these clashed, as they sometimes did.

Richard Smith Coxe was born in Burlington, New Jersey, in 1791. In colonial days, Burlington served as the capital of West Jersey. The New Jersey Assembly met there every other session, alternating with the East Jersey capital of Perth Amboy. One of the more affluent towns in the mid-Atlantic, Burlington was a center of commerce as well as a seat of government. 
Although founded by Quakers, Burlington had a sizable Anglican congregation, which included the Coxes, established by the Society for the Propagation of the Gospel in Foreign Parts in 1703. With the removal of the capital of New Jersey to Trenton in 1790, Burlington's political importance declined. Ambitious local politicians and lawyers then had to look beyond Burlington. ${ }^{1}$

Richard Smith Coxe's nearly impeccable political pedigree went back generations. He was a descendant of Daniel Coxe (1640/1-1730), an early deputy governor of West Jersey. His son Daniel (1673-1739), apparently having ingratiated himself with the governor Lord Cornbury, served as commander of royal military forces in New Jersey. ${ }^{2}$ A cousin, also named Daniel Coxe (1741-1826), won royal appointment to the West Jersey Council in 1771. When the American Revolution broke out, he became a staunch Loyalist. As such, he articulated opinions concerning property rights, echoed years later by Richard Smith Coxe. On July 4, 1775, he wrote about his fears of the impending revolution in British North America. "Men of property" would become "a mark at once for popular fury, and those who are esteemed friends to Government devoted for destruction." 3 He ultimately fled to England, and he lost all of his property, valued at over $£ 40,000$, in New Jersey. ${ }^{4}$

William Coxe (1762-1831), father of Richard Smith Coxe, married Rachel, a daughter of Richard Smith, also of Burlington. William Coxe served as a vestryman of St. Mary's Episcopal Church in Burlington. Politically, he looked beyond the one-time provincial capital, becoming a leader of the Federalist party when the First Party System emerged in the 1790s. In 1813, Coxe

\footnotetext{
${ }^{1}$ Burlington was the political and economic powerhouse of West Jersey before the revolution. See Liam Riordan, Many Identities, One Nation: The Revolution and Its Legacy in the Mid-Atlantic (Philadelphia: University of Pennsylvania Press, 2007), 26-27.

${ }^{2}$ William Nelson, Biographical and Genealogical Notes from the Volumes of the New Jersey Archives (Baltimore: Clearfield Company, reprint, 1989), 81-83. Cornbury and Hunter both served simultaneously as governor of New York and New Jersey.

${ }^{3}$ New Jersey Archives, XVIII, 259-260.

${ }^{4}$ Nelson, 85-86.
} 
won election to the United States House of Representatives on a "Peace Ticket" formed by

Federalists and Democratic-Republicans who opposed the declaration of war on Great Britain in

1812. Coxe led successful efforts by the once-moribund Federalist party in New Jersey to revive, if only fleetingly, its fortunes. Indeed, in 1812 and 1813, the Federalists captured control of the New Jersey legislature and its congressional delegation for the first time in over a decade. ${ }^{5}$

When in Washington, William Coxe wrote at least two letters loaded with political observations to his son, Richard. On December 22, 1813, William Coxe voiced his skepticism about the Madison administration's conduct of the war. He criticized the administration's continuation of the embargo, perceiving it as a "substitute for arms." He also pointed to the failure of the campaign to conquer Canada, which "they [the administration] say must be ours at any price of men or money." He noted the inability to find a capable field commander, one who could "combine in his own person the talents to conduct the war, silence the envy of ambitious and unprincipled rivals, check insubordination, and possess public confidence." Coxe suggested William Henry Harrison as a possibility, but doubted even his credentials. ${ }^{6}$

William Coxe saw the "system of retaliation," the embargo, as "more destructive to individuals and disgraceful to the belligerents." He was also unhappy with the administration's decision to seek a loan of $\$ 20$ million to fund the war "while all other modes of raising revenue will I suspect be abandoned." Coxe hoped for successful negotiations, but with no word on the

\footnotetext{
${ }^{5}$ Ibid., 89-90. Federalists joined forces with Democratic-Republicans who opposed the declaration of war on Great Britain to form a "Peace Ticket" in New Jersey's Third Congressional district. Coxe and Jacob Hufty of Salem won election to Congress early in 1813 on that ticket. David Hackett Fischer identified William Coxe as one of the "Young Federalists" who accepted political innovations such as partisan competition and contested elections between "standing" political parties. Fischer, The Revolution of American Conservatism (New York: Harper and Rowe, 1965), 329.

${ }^{6}$ William Coxe, Washington, DC, to Richard Smith Coxe, Burlington, December 22, 1813, Coxe Papers, Special Collections, Rutgers University, New Brunswick, New Jersey (hereafter: RUSC). Coxe's response was mild compared to the response of Federalists in Massachusetts, where opponents of the embargo urged state legislation to thwart the impact of the embargo. See Richard H. Buel Jr., America on the Brink: How the Political Struggle over the War of 1812 Almost Destroyed the Young Republic (New York: Palgrave Macmillan, 2005), 189-92.
} 
"Russian mission,"7 he confessed that his hopes for peace were "much diminished." Even so, he did not believe it "so distant as many others appear to think." Ultimately, Coxe believed that more depended on "events now transacting in the north of Europe than all the blood and treasure which can be lavished on this side of the Atlantic." William Coxe found consolation in his appointment to the powerful House Ways and Means Committee, its only Federalist member. "It gives even a member of the opposition some consideration to be selected for an important committee."

Coxe again wrote his son on March 6,1814. He noted that Congress was set to adjourn on April 11, when he would "hail with joy the period of my departure from this scene of political intrigue and corruption." He believed that "the acts of the government breathe the spirit of war to its most violent extent." Even so, he hoped that the peace commissioners, still in St. Petersburg, could negotiate an end to the war. He again decried the embargo, noting that a motion for its repeal lost only by a small margin in the House of Representatives, and he expressed his hope that the "prospect of peace" would lead to its removal. Coxe did find time for social life, spending an evening with Robert Goodloe Harper, a Federalist of South Carolina, "highly entertaining" but "too diffusive as a speaker." He also had dinner with the "uncommonly intelligent Mr. [Langdon] Cheeves" of South Carolina, who had "squandered his usefulness by the impropriety of his conduct," but who had nonetheless won election as Speaker of the House of Representatives when Henry Clay resigned to join the American negotiators seeking to end the war with Great Britain. ${ }^{9}$

\section{Young Coxe goes to Washington, DC}

\footnotetext{
${ }^{7}$ A reference to peace negotiations, then taking place in St. Petersburg, Russia, later moved to Ghent, now in Belgium.

${ }^{8}$ William Coxe to Richard Smith Coxe, December 22, 1813, RUSC.

${ }^{9}$ William Coxe, Washington, DC, to Richard Smith Coxe, Burlington, March 6, 1814, RUSC.
} 
Richard Smith Coxe prepared for a legal career as he corresponded with his father. Coxe graduated from the College of New Jersey in 1808, after which he read law with Judge William Griffith, another prominent Burlington County Federalist. He was admitted to the New Jersey bar at the May 1817 term of the state Supreme Court. Just before his admission to the bar, he married his mentor's daughter, Susan Griffith, on June $23,1816 .^{10}$

Within five years of his admission to the bar, in 1822 Coxe left Burlington to practice law in Washington, DC. This decision offered both advantages and disadvantages. Coxe was, of course, able to pursue a potentially lucrative and prestigious career in the nation's capital, but the relocation also foreclosed the possibility of a political career, since the District of Columbia did not, at that time, have an elected local government, nor did it have representation in the United States Congress.

Before moving to Washington, Coxe realized that young Federalists had few political options. After the brief resurgence in 1812, New Jersey Federalists saw their short-lived gains reversed by 1814. In a speech to the Washington Association of Philadelphia on February 22, 1814, Coxe bemoaned the "systematic exclusion of the friends of Washington from the important offices of state," replaced by "determined foes to religion and to good government, to order and to economy." For Coxe and other aspiring young Federalists, the chances of winning elective office or receiving an appointive office were slim. Furthermore, Burlington's diminished political importance gave Coxe little chance for political or professional advancement there. ${ }^{11}$

The demise of the Federalist party no doubt motivated Coxe to take the course that he took. On January 13, 1822, Coxe wrote Garret Wall, another young Federalist, about the

\footnotetext{
${ }^{10}$ Nelson, 91.

${ }^{11}$ Richard Smith Coxe, An Oration Delivered Before the Washington Society of Philadelphia (Philadelphia: William Fry, 1814), 14-15. Fischer, 329.
} 
changing political landscape. ${ }^{12} \mathrm{He}$ first posed a rhetorical question: "What would you say—what would my Jersey friends say-were I to renounce the political principles in which I have been nurtured and become as you say a patriot?" Dissatisfied with the "absolute absurdity" of "talking about distinctions that have long ceased to exist," Coxe now believed himself "more of a democrat than many who pass under the name." Nonetheless, he went on to say that, while not formally a "Democrat," he did not oppose "the present [Monroe] administration in principle or practice." Indeed, he had "scarcely" heard "the terms [party names]" since moving to the nation's capital. ${ }^{13}$

Coxe then acknowledged his inability to seek elective office in the nation's capital. "My political existence is terminated;" he could "never come forward in Congress" and could "have no political influence." But Coxe saw an advantage in such circumstances. "I talk as I please and am very well satisfied being regarded as a non-combatant." But his circumstances did not prevent him from offering advice to Wall. He urged Wall to "disencumber yourself from the weight of a fallen party," noting that the contest would now be between men, not parties. Even

\footnotetext{
${ }^{12}$ For reference to Wall's early political affiliation, see Herbert Ershkowitz, The Origins of the Whig and Democratic Parties in New Jersey Politics (Washington: University Press of America, 1982), 13. In addition, like many young Federalists, Coxe faced limited opportunities in the political arena. Democratic-Republicans, now entrenched in office, left Federalists to "languish in obscurity and perish with neglect." Albrecht Koschuch, "Young Federalists, Masculinity and Partisanship during the War of 1812" in Jeffrey L. Pasley, Andrew W. Robertson, and David Waldstreicher, Beyond the Founders (Chapel Hill: University of North Carolina Press, 2004), 169.

${ }^{13}$ Ronald P. Formisano questioned the very existence of a strong party system before circa 1840, arguing that the "alleged First Party System," lacking clearly organized parties, drew on the deferential political culture of the eighteenth century "as much as it forecast the shape of future politics." Rather, Formisano saw a transitional phase from "deference to participation." Federalists could thus find a new political identity and form political alliances in a fluid environment. Before Andrew Jackson emerged on the scene lacking a major polarizing political issue, personalities dominated political discourse in the 1820s, adding the variant of personality to Formisano's devaluation of the role of party in the early republic's political culture. The Wall-Coxe correspondence provides an example of how politicians sought a political identity, based on their support of individuals seeking the presidency in 1824. Ronald P. Formisano, "Deferential-Participant Politics: The Early Republic's Political Culture 1789-1840," in The American Political Science Review 88:2 (June 1974), 473-485.
} 
so, Coxe foresaw the emergence of a new party system and "should you chance to join the strongest [new] party all your political ambitions will be realized."14

Once in Washington, Coxe employed connections, some no doubt established by his father, to make acquaintances with notable political figures from his home state and elsewhere. Coxe could not resist the temptation to share his impressions of some of the "great men" he had met in Washington. President James Monroe, "a plain gentlemanly Virginian," was "affable and pleasant." Coxe was "much pleased” with Senator John C. Calhoun of South Carolina, impressed with his "considerable quickness of mind." The British minister to Washington, Lord Canning, also impressed him: "affable" in spite of his "rather stiff and ceremonious bearing." As for Congress, Coxe found the proceedings of the Senate "much more agreeable" than those of the lower house, having "heard nothing like rant or declamation in its deliberations." 15

Coxe soon formed a crucially important political alliance, one that transcended old party allegiances and advanced his own career, with Samuel Southard, formerly a Democratic Republican. ${ }^{16}$ The Coxe-Southard correspondence began in earnest in 1823, when the Presidential contest of 1824 was heating up. Both Southard and Coxe initially supported the candidacy of South Carolinian John C. Calhoun, then a firm nationalist. Writing Southard on March 31, 1823, Coxe waxed optimistic about Calhoun's prospects. He had information “of the most agreeable kind from the western states," and urged Southard to promote Calhoun's cause in

\footnotetext{
${ }^{14}$ Even so, Coxe's comments here suggest that, before the disintegration of the Federalists, parties had indeed provided a means of political and ideological identification, even if not as institutionalized as they became after 1840, but exerting a greater role in political discourse than suggested by Formisano.

${ }^{15}$ Richard Smith Coxe, Washington, DC, to Garret Wall, Trenton, January 13, 1822, Series 1, Box 1, Folder 18, MS0275, Special Collections, George Washington University, Washington, DC. James Sterling Young pointed out that newcomers such as Coxe had to "fit in" to a Washington where regional connections strengthened by friendships formed in boardinghouses came to outweigh party organizations. The collaboration between Southard and Coxe, who did not share a partisan background, lends credence to this argument. For an account of such "networking" in the nation's capital in the so-called Era of Good Feelings, see Young, The Washington Community 1800-1828 (New York: Columbia University Press, 1966), 98-106.

${ }^{16}$ Michael Birkner wrote a full biography of Southard, discussing his political migration to the Whig Party after the demise of the First Party System. Samuel Southard: Jeffersonian Whig (Rutherford, New Jersey: Fairleigh Dickinson University Press, 1984).
} 
New Jersey. "Cannot something be done in aid of this cause in our Jersey papers?" Coxe inquired. The state seemed "favorably disposed" toward Calhoun. With quick action, "the current might be effectually set" to build momentum for Calhoun. "You may suppose I am becoming something of a politician," Coxe wrote to Southard, but only "a good deal of anxiety about who are to be our rulers" sparked this concern. ${ }^{17}$

Personal along with political matters emerged in the Coxe-Southard correspondence. Coxe mentioned changes in the Post Office Department going beyond the replacement of the Postmaster General. Coxe also hinted at a presidential appointment for himself. He noted that he had spoken with Secretary of State John Quincy Adams, and the secretary had noted President Monroe's "great good will towards me," with a "strong inclination to gratify my wishes." As for his fledgling law practice, Coxe noted that he had "made my appearance in one or two cases and hopes are held out that ere long have as much business as I desire."18

Coxe again updated Southard on affairs related to his career on July 7, 1823. He noted that his Washington law practice was still growing slowly; he relied on Southard to collect a debt of $\$ 1,100$ in New Jersey for "my maintenance until my business here should prove productive." Even so, discouragement crept into Coxe's discourse, as he reflected on a 'trying situation to be left nearly destitute in a strange land." Nevertheless, he hoped for the best. He sought a position as secretary of an unnamed commission and urged Southard to write Calhoun, asking him to exercise his influence with his father's old acquaintance, Representative Langdon Cheeves of South Carolina, "without making it the sole object of your letter." Coxe felt that Calhoun had "intimated his desire to serve me" and Southard's reminder could do no harm. Finally, Coxe noted that "nothing of any great moment" had occurred on the Fourth of July, in spite of the

\footnotetext{
${ }^{17}$ Richard Smith Coxe, Washington, DC, to Samuel Southard, Trenton, March 31, 1823, Southard Papers, C0250, Rare Books and Special Collections, Princeton University, Princeton, New Jersey (hereafter: RBSCP).

${ }^{18}$ Ibid., May 16, 1823.
} 
"glorious opportunity" to express support for independence movements in Greece and South America, as well as efforts to install a constitutional monarchy in Spain. Many Americans viewed such efforts to promote independence and constitutional government with sympathy. ${ }^{19}$

Perhaps with his own advancement in mind, Coxe supported Southard's successful efforts to become Secretary of the Navy. On July 31, he noted the removal of obstacles to Southard's appointment to that office, and he hoped to "shortly have the pleasure of seeing you established at Washington to your satisfaction." Secretary of War Calhoun had, on the previous Sunday, "mentioned the report of my countryman coming on here." Coxe's own legal business continued to grow slowly; he reported that "my prospects are brightening a little professionally." Despite the slow, no doubt frustrating, pace of growth, Coxe preferred "taking my chance here to Burlington."20

Presidential politics resurfaced in a letter Coxe wrote to Southard on August 16, 1823. Reporting a "good deal of private confab" with Calhoun, he noted that the secretary would make an announcement, its premature disclosure prevented by "state etiquette." He also ruled out a “coalition" between John Quincy Adams and Calhoun, stating that such talk "must be put down." He also noted the exertions by Adams and Crawford supporters to define the presidential contest as solely between those two men. Coxe believed that their relative strengths were based in each other's weaknesses. A choice between them was one of "the least of two evils."

This problem "should now be cured" by the advancement of John C. Calhoun. Calhoun, "who comes from the South and [was] educated in the North," would sooth sectional feelings and attend to the interests of both regions, as well as those of the mid-Atlantic states. Calhoun

\footnotetext{
${ }^{19}$ Ibid., July 7, 1823. As Spain's American colonies revolted to gain independence, Spain itself was in the midst of the Trienio Liberal, a brief, unsuccessful effort to implement a constitutional government. That effort ended in 1823, with the restoration of Ferdinand VII as an absolute monarch.

${ }^{20}$ Ibid., July 31, 1823.
} 
could "lend all his strength to the cause of commerce, agriculture and manufactures," in addition to pursuing the "important objects of national defense." And he would not "awaken and rekindle all that feeling, now happily more than half extinct between federalist and democrat," befriending "the intelligent, the wise and good of all parties and all sections."

Indeed, Coxe felt that William Crawford "is considered hors du combat," hinting that the candidate himself was considering a return to his native Georgia. The presidential contest was between "A [Adams] and Cn [Calhoun]." Coxe again urged Southard to appeal, on Calhoun's behalf, to the people of New Jersey. "Have something appear in the Trenton True American" to promote the South Carolinian's cause. Coxe further encouraged Calhoun by pointing out that Ohio was "decidedly with us." New York provided "great encouragement" and North Carolina was "at worst balanced." "This ground should now be taken to ensure the accomplishment of our wishes." He further urged Southard to contact local leaders such as Lucius Q. C. Elmer of Cumberland County and Thomas Cook of Middlesex to advance the Calhoun cause across the state. $^{21}$

By November of 1823, Southard had become Secretary of the Navy and talk of the presidential campaign had largely disappeared from the correspondence between the two men. Instead, discussion focused on appointments in Southard's department. Southard himself evidently wished to remain in charge of the Navy Department after President Monroe left office in March 1825, and he thus distanced himself from politics. Even so, Southard continued to quietly back Calhoun until March of 1824, when a convention held in Harrisburg, Pennsylvania, threw its support to Andrew Jackson and ignited the candidacy of the hero of New Orleans, thus

\footnotetext{
${ }^{21}$ Ibid., August 16, 1823. Coxe rendered this judgment about one month before Crawford suffered a stroke in September 1823. For a discussion of the presidential election of 1824 in New Jersey, see Herbert Ershkowitz, "The Election of 1824 in New Jersey" in Proceedings of the New Jersey Historical Society (April 1966), 113-132.
} 
undercutting Calhoun's chances. After this event, Southard "resolved to maintain a benign neutrality."22

Coxe's friendship with Southard proved beneficial to both men. Indeed, at this point, Richard Smith Coxe's legal career took a more precise direction as he began to focus on cases involving international affairs. The cases that brought Coxe some prominence involved American military personnel or merchants operating overseas. Furthermore, they involved matters of international law. Coxe defended the interests of his clients in the context of appropriate international law and custom. His friend Samuel Southard, who did remain Secretary of the Navy after John Quincy Adams succeeded James Monroe, handed him such an opportunity. Coxe did not completely abandon politics, but his law practice gained preeminence. Overall, both his legal and political endeavors reflected his efforts to establish the position of the United States as an accepted and respected member of the international community in the context of representing his clients.

Surely because of Southard's patronage, Richard Smith Coxe won appointment as judge advocate for the navy by 1825 , when he presided over the court martial of Commodore David Porter. Porter, in command of the United States naval forces in the Caribbean and Gulf of Mexico, had ordered a raid on Fajardo, Puerto Rico, supposedly to recover goods stolen from an American merchant at St. Thomas, in the Virgin Islands. Porter's superiors questioned his judgment in ordering a hostile landing on Spanish soil and investigated the matter. Porter had always had an icy relationship with Southard, and he questioned the objectivity of Coxe, appointed as judge advocate by the secretary. He thus challenged Coxe's fitness to serve, even

\footnotetext{
${ }^{22}$ Birkner, 65-70. Gaining the support of New Jersey politicians such as Southard and his friend Coxe fit in with Calhoun's strategy of winning support in the North and mid-Atlantic. Such efforts foundered when the convention in Harrisburg gave unexpected support to Andrew Jackson at Calhoun's expense. See Irving H. Bartlett, John C. Calhoun: A Biography (New York: W. W. Norton \& Company, 1991), 113-119.
} 
asserting that Coxe had published an anonymous pamphlet setting forth the truth of allegations against him, prejudging the case. Ultimately, a court martial found Porter guilty of two charges, but it imposed a lenient sentence of six months' suspension from active duty. ${ }^{23}$

In the midst of this activity, Coxe took the time to write his sister, Margaret, in West Point, New York, about his life in the capital. Writing from his home in Georgetown, he looked forward to returning to New Jersey. "In a few days," he and Samuel Southard planned to leave the nation's capital. "Don't you wish me joy that the courts martial are over?" he queried his sister. He rejoiced that after discussions with President John Quincy Adams, there was "not a single act of mine since the commencement of the courts which had not had his entire approbation." With this satisfying development, Coxe looked forward to time with his family in New Jersey. ${ }^{24}$

The Porter trial enhanced Coxe's reputation as an expert in international maritime law. In 1827, he presented a petition to Congress concerning an episode in the Mediterranean back in 1804. In the conflict with the Barbary States, an American vessel, the Intrepid, had seized the Philadelphia, another American vessel captured by the government of Tripoli. The officers and crew of the Intrepid — or their heirs — insisted that they were entitled to prize money for their actions. Coxe argued that the Intrepid's crew held property rights to the vessel they had seized and were "entitled to the full value of the property captured." Cox further argued that American

\footnotetext{
${ }^{23}$ David F. Long, Nothing Too Daring: A Biography of Commodore David Porter, 1789-1843 (Annapolis: United States Naval Academy Institute, 1970), 230-255. Ershkowitz discussed the impact of this affair on Southard's interaction with New Jersey politicians before Southard more formally affiliated himself with the anti-Jacksonians. Southard remained on friendly terms with New Jersey Jacksonian politicians before breaking with them, and observers in Washington noticed that. See Ershkowitz, The Origin, 62-63.

${ }^{24}$ Richard Smith Coxe, Washington, DC, to Margaret Coxe, West Point, New York, August 12, 1825, BledsoHerrick Papers, MC290, Schlesinger Library, Radcliffe Institute for Advanced Study, Harvard University, Cambridge, Massachusetts.
} 
courts had sustained this position and that the Constitution itself prohibited government seizure of such property for "public purposes" without compensation. ${ }^{25}$

\section{The Emergence of the Second Party System}

Coxe once again turned his attention to political matters as the presidential election of 1828 approached, but he showed no particular concern with developments in New Jersey. In August of 1827, Coxe felt compelled to warn his friend Samuel Southard, still Secretary of the Navy, of the consequences of correspondence "of a private and consequential character" with Andrew Jackson, clearly President Adams's chief rival. Warning Southard that he had been "shrewdly suspected" of carrying on this correspondence, Coxe warned that it "has given occasion to revive the old story of your being faithless to the administration." Southard's enemies resorted to "jesuitical means to give it that color." Coxe pointed out that a note had been dropped in a committee room in the Capitol and "read by a decided administration man." Coxe urged Southard to address and clear up the matter as quickly as possible.

In the same letter, Coxe discussed prospects for the reelection of John Quincy Adams in 1828. Coxe reported that the administration was "decidedly gaining ground rapidly." Reports from Pennsylvania, New Jersey, and New York encouraged Coxe. Correspondence between General Jackson and Secretary of State Henry Clay, presumably detrimental to Old Hickory, "have come out very opportunely.” In addition, a speech Clay delivered at Lexington, Kentucky, "produced a wonderful effect." Coxe recounted an episode where the speech was read on board a steamboat in New York and "only one individual out of a hundred did not testify his

\footnotetext{
${ }^{25}$ Document 333, House of Representatives, 19th Congress, 1st Session, February 7, 1827. The House did not immediately respond to this petition.
} 
approbation." Coxe further noted that, in New York, some men "publicly proclaimed as Jackson men" had now become "administration men." 26

Coxe's optimism proved misplaced as Jackson defeated President John Quincy Adams in 1828. After Southard's departure from Washington, Coxe supported Henry Clay, who had emerged as the leader of the National Republican, later the Whig, opposition to Jackson. On July 5, 1830, Coxe addressed "mechanics and other citizens of the city of Washington, friends of Henry Clay." Coxe's support of Clay focused on the issues of internal improvements and foreign policy. He believed that the Treaty of Ghent, which ended the War of 1812, and the end of the Napoleonic Wars in Europe, "imposed upon statesmen a necessity to accommodate their political views and movements to this new aspect of things.... The entire situation of the Christian world was changed." Peace in Europe, and thus across the Atlantic, opened the doors to domestic growth and development in an expanding United States. ${ }^{27}$

Echoing Clay and his congressional allies, Coxe saw the "most important means of effecting these desirable ends were internal improvement and the encouragement of domestic industry." Coxe cited such improvements in New York, Ohio, and Pennsylvania as examples. Closer to home, he pointed to the work on the Chesapeake and Ohio Canal, an effort to construct a waterway between the Ohio and Chesapeake watersheds. Indeed, Coxe himself chaired a convention of citizens of Maryland, Pennsylvania, Ohio, Virginia, and the District of Columbia who drafted a petition to Congress urging continued funding for the canal. This petition

\footnotetext{
${ }^{26}$ Richard Smith Coxe to Samuel Southard, August 2, 1827, RBSCP.

${ }^{27}$ Address Delivered by Richard Smith Coxe before the Mechanics and Other Citizens of the City of Washington, Friends of Henry Clay on Monday, July 5, 1830 (Washington: Peter Force, 1830), 3-6.
} 
expressed certainty that internal improvements such as the canal would stimulate both regional and national economic growth. ${ }^{28}$

Coxe pointed out that both the Monroe and Adams administrations had supported internal improvements. In so doing, they "fixed their eyes steadily upon the public welfare, above local prejudices and animosities." Such policies, according to Coxe, benefited every segment of the American economy, especially farming, domestic manufacturing, and internal commerce. Henry Clay's "American System" would be "cherished" by the wisest statesmen. In sum, internal improvements, coupled with international tranquility, "contribute greatly to cement the union; it is fact-it is history." 29

Andrew Jackson's use of the veto now threatened to negate the salutary benefits of internal improvement legislation passed by Congress. Coxe believed that Jackson's vetoes "thwart the interests and counteract the wishes" of most Americans. Jackson had acted disingenuously; he had "veiled his opinions in obscurity and doubts." In his campaign for the White House, Jackson sought to "claim the support of the people without condescending to inform them how he will act upon questions they have decided." His "forms of expression" conveyed to party leaders and voters that he "approves and will support the opinions of each." Jackson's conduct exemplified "studied ambiguity" in practice. ${ }^{30}$

Coxe critiqued other actions of the Jackson administration in addition to internal improvements. The patronage policies of Jackson's administration handed public offices to the "profligate and venal calumniators and slanderers." Official government documents became a means to "dole out personal abuse and gross malignity." Printers won government jobs "in

\footnotetext{
28 "Memorial of a Convention of Citizens of the States of Maryland, Virginia, Pennsylvania, and Ohio, and of the District of Columbia Asking Further Aid of Congress for the Completion of the Chesapeake and Ohio Canal" (Washington: Gales and Seaton, for the 23rd Congress, 2nd Session, Document 32, House of Representatives).

${ }^{29}$ Coxe, Address, 7-9.

${ }^{30}$ Ibid., 9-10.
} 
proportion to their devotion to the cause." Coxe also assailed Jackson's policies toward Native Americans, pointing to their violation of the "pure morality of the Christian's practice." In sum, Coxe found the "bold, bad men now elevated to power" repulsive. ${ }^{31}$

What was the alternative? Coxe saw a "brilliant stream of glory ... gleaming along the western heavens": Henry Clay of Kentucky. Coxe also praised Clay's ally, "the voice from the East," proclaiming "liberty and union, now and forever, one and inseparable," Daniel Webster of Massachusetts, citing Webster's response to Robert Hayne of South Carolina on January 26, 1830. Coxe also praised anti-Jacksonians such as John M. Clayton of Delaware, William Sprague of Rhode Island, John Holmes of Massachusetts, “and others.” But Henry Clay was clearly Coxe's hero. Contrary to Jackson's practice of "the art of a sphinx," Clay's principles "are emblazoned upon his shield and graven upon his buckler." The United States, according to Coxe, must turn to "that sagacious statesman, the profound legislator, the disinterested patriot, the foully calumniated-HENRY CLAY."32

Clay himself commended Coxe's polemics, stating that the committee's "active assertions will, no doubt, be productive of much good." ${ }^{33}$ Coxe followed up on the committee's efforts by preparing editorials for Washington's Daily National Record, a newspaper opposed to the Jackson administration. Writing to Clay, the editor, William Prentiss, noted that Coxe was "very attentive to our department." Furthermore, Coxe's brother-in-law, William Griffith of Burlington, New Jersey, had also contributed to that newspaper's editorial page. ${ }^{34}$

Richard Smith Coxe returned to his alma mater at Princeton on September 24, 1833, to deliver a commencement speech that set forth his Whig political philosophy. He began his

\footnotetext{
31 Ibid., 10-11.

${ }^{32}$ Ibid., 12-15.

${ }^{33}$ Robert Seager, ed., Papers of Henry Clay, VIII (Lexington, University Press of Kentucky, 1984), 268.

${ }^{34}$ Ibid., 369.
} 
remarks by noting the proliferating range of fields of study at his alma mater, mentioning the departments of classical literature, the Orient, medicine, law, botany, as well as other disciplines. Moving to the substance of his address, Coxe contrasted the tradition-bound governments of Europe with that of the United States. Even though the relics of feudalism were decaying in Europe, they had not completely crumbled. Even so, times were changing. The British nobility survived only by "extraneous supports to preserve them from falling into utter dilapidation." The need for an "enlightened public opinion" arrested France's development. Even in more authoritarian Prussia, public opinion made itself heard "in advance of government," "however crude in its character and wrong in its conceptions." 35

There was "no such struggle" in the United States. Americans acknowledged and respected public opinion. Elected and appointed officeholders were "an accurate standard by which to measure the virtue and intelligence which exist among the people." Instead of "standing armies of hired mercenaries" in America, "every citizen was inured to the use of arms." But Americans had to remain vigilant and virtuous. "History furnishes no example of a people being deprived of freedom, until vices and corruption had betrayed its external defenses and opened the gate for the invasion for the foreign foe." Private virtue and national prosperity were inextricably linked. ${ }^{36}$

Coxe also encouraged the "benignant" spirit of religion, which "fostered a bold and undaunted spirit of independence" along with order and stability. Modern and Christian countries

\footnotetext{
${ }^{35}$ Richard Smith Coxe, An Address Delivered in the Church of Princeton the Evening before the Commencement of the College of New Jersey, September 24, 1833 (Princeton: Baker and Connolly, 1833), 5-28. Throughout this oration and his address to the workingmen of Washington in 1830, Coxe set forth the governmental philosophy of the emerging opposition to Andrew Jackson and the Democratic party. Coxe's thoughts on government and its social and economic roles reflect those set forth by contemporaries who had affiliated with the Whig Party, including protection of property rights and maintenance of social order in the context of a "mixed balanced polity." Such a desire for balance also motivated Coxe and other Whigs to oppose the aggrandizement of the executive branch they attributed to Andrew Jackson. See David Walker Howe, The Political Culture of the American Whigs (Chicago: University of Chicago Press, 1979), 77, 199, 210-217.

${ }^{36}$ Ibid., 30-32.
} 
"witnessed revolutions without murders and civil wars without massacre." Christianity tamed, in Coxe's view, "the corrupting passions of men." Perhaps with the French and Latin American revolutions in mind, Coxe believed that the diffusion of "religious education" would secure the United States against "foreign oppression and domestic convulsion."37

\section{A Whig View of International Relations and Domestic Politics}

Furthermore, Coxe linked his Whiggish views of order and property rights with his thoughts on international order and stability, particularly in the context of the revolutions that had swept the Americas. Coxe had already become a specialist in international maritime law, manifested by his work on the claims of Americans against the former French colony of St. Domingue. Years after the upheaval that had begun with the revolt of the enslaved in that former colony in 1791, Americans still sought to recover losses. In 1833, Coxe published a pamphlet dealing with the legality of American claims regarding goods seized, confiscated, or destroyed during the uprising in the French colony when Haitians fought for and established their independence. Coxe argued that those claims were not necessarily valid, depending on their timing and specific circumstances. A treaty with France stipulated that the French government would compensate the United States government, which would in turn distribute the proceeds among the claimants. Many Americans filed claims dating back to the beginning of the nineteenth century. ${ }^{38}$

Timing was crucial. Coxe argued that since France had not recognized Haitian independence, the French government had the right to seize vessels attempting to trade with a rebellious colony. A policy decision by President John Adams complicated matters. On February

\footnotetext{
${ }^{37}$ Ibid., 32-34. The religion that Coxe identified as "benignant" was surely the Protestant Christianity that dominated American social and political culture since the Puritan colonization of New England, itself the legacy of the Protestant Reformation and religious strife in England.

${ }^{38}$ Richard Smith Coxe, St. Domingo Claims (Philadelphia, 1833).
} 
9, 1799, Adams had signed a bill extending the embargo on trade with France and its colonies in the midst of the quasi war with that nation, but he allowed American vessels to enter ports in the rebellious colony of St. Domingue as of August 1, 1799. After the conclusion of an agreement to end Franco-American hostilities in 1800, President Thomas Jefferson, after taking office in 1801, recognized French sovereignty over the colony, dealing with Toussaint Louverture, but only in his official capacity of French Governor General. ${ }^{39}$

Coxe argued that the French government had the right to seize vessels trading with a rebellious colony, Adams's action during the quasi war notwithstanding. The Jefferson administration's acknowledgment of admittedly fragile French sovereignty strengthened Coxe's argument favoring the colonizing power's prerogatives. A decision by the United States Supreme Court further buttressed Coxe's case. In Rose v. Himely (4 Cranch 241), Chief Justice Marshall and his associates ruled that until France relinquished its claim to sovereignty, "courts of justice must consider the ancient state of things as remaining unaltered and the sovereign power of France as still subsisting." To Coxe, the sovereign rights of the colonizing power outweighed claims to independence and the aspirations of colonial subjects. ${ }^{40}$

The dispute acquired greater importance in the light of independence movements sweeping across Latin America during the 1810s and 1820s. The right of colonies to separate from "Metropolitan Europe" depended on the colony, not the metropolis, some argued, but Coxe asserted that the history of the proceedings with "St. Domingo" provided "ample and conclusive refutation of this idea." The United States, or American merchants, had added "partial and

\footnotetext{
39 "Proclamation of June 26, 1799, Regarding Commerce with St. Domingo" in A Compilation of Messages and Papers of the Presidents, Joint Committee on Printing, 52nd United States Congress, Washington, DC.

${ }^{40}$ Coxe, St. Domingo Claims, 19-22. For a discussion of the legal ramifications of trade with colonies in transition, see Edwin D. Dickinson, "The Unrecognized Government or State in English and American Law in Michigan Law Review 22:1 (November 1923), 29-45. For a discussion of trade relations between the United States and St. Domingue, see Gordon S. Brown, Toussaint's Clause: The Founding Fathers and the Haitian Revolution (Jackson: University Press of Mississippi, 2005), 138-142 and 184-185.
} 
iniquitous" innovations to international law. The convention with France referred solely to injuries sustained by Napoleon's Berlin and Milan decrees; it did not refer to trade with St. Domingue conducted before the promulgation of those decrees. ${ }^{41}$ Coxe concluded that the claimants lacked "any foundation in law." If the voyage itself was illegal, the capture of the vessels involved was perfectly lawful. ${ }^{42}$

Coxe thus opposed the concept that the United States should encourage the independence movements in the Americas that he had earlier espoused in his letter of July 7, 1823, to Samuel Southard, putting him at odds with Henry Clay. Coxe took the position that a new nation was not truly free until the parent country had formally recognized its independence. He even raised the example of the United States and Great Britain between July 4, 1776, and the British recognition of independence by the Treaty of Paris in 1783 . The British, by this reasoning, had every right to intercept commerce to the new American republic before the signing of the treaty. A more mature United States, seeking acceptance in the international community, should adopt the British position as a precedent in dealing with the new American republics. ${ }^{43}$

Still, Coxe had not abandoned his interest in domestic politics, reflected in his active support of William Henry Harrison, for whom he campaigned in 1840. Before the election, Coxe had drawn fire for his support of Harrison's bid for the presidency. In October of 1840, he had journeyed to Columbus, Ohio, to campaign for the general. The Democratic Ohio Statesman resurrected old partisan divisions, blasting Coxe as a "Federalist missionary from Washington," a "violent old Blue Light Federalist of Washington City." The Statesman accused Coxe of making

\footnotetext{
${ }^{41}$ Ibid., 5 .

${ }^{42}$ Ibid., 23-24.

${ }^{43}$ Ibid., 18-24. Coxe's reasoning can be placed into the context of American efforts to win acceptance, especially by the powers of Europe. Eliga H. Gould argued that a need to win international acceptance motivated American policymakers, what Gould called a quest for "treaty-worthiness." Although Coxe did not hold a policymaking position, his arguments, coupled with his political connections, reflect such efforts. Eliga H. Gould, Among the Powers of the Earth: The American Revolution and the Making of a New World Empire (Cambridge: Harvard University Press, 2012), 11.
} 
undue profits while he served as judge advocate for the Navy Department while Harrison served in the United States Senate. According to the Statesman, Coxe was reimbursed $\$ 7,329$, and he had received $\$ 3,700$ from the Navy Department's contingency fund, $\$ 200$ more than the salary of the attorney general. As a senator, "that admirable economist Billy Harrison . . that warm friend and abettor of Coxe and Southard ... winked at the extortions and frauds of Coxe." Now Coxe had come to Ohio "to bolster up his old black cockade friend."44 The Statesman averred that Harrison had done nothing about Coxe's alleged misconduct, clearly an effort to divert attention from Whig claims about rampant political cronyism in the Van Buren administration. ${ }^{45}$

Coxe's Whig sentiments emerged even more forcefully and more broadly in his eulogy of Harrison, the first Whig elected President, delivered on June 24, 1841, in Washington, DC. President Harrison had died of pneumonia on his thirty-second day in office. Most of the oration summarized Harrison's achievements, but Coxe's Whig principles emerged from the rhetoric. Coxe was especially careful to contrast Harrison's conception of executive authority with that of Andrew Jackson. "Without political influence to sway, without wealth to corrupt, without any adventitious or dazzling attractions to mislead, his strength consisted in the memorials of his past life, and the evidence they furnished of his patriotism, his integrity, and his wisdom."46

In his short time in the White House, Harrison "avowed his determination to be guided by no other principles than those of rectitude and patriotism" and to "assume no other powers save those which the Constitution granted." When Harrison died, "the deep grief which pervaded the

\footnotetext{
${ }^{44}$ Ohio Statesman, Columbus, Ohio, October 21, 1840. The reference to Coxe's Federalism suggests that partisan divisions nearly three decades old faded slowly and had greater durability than suggested by Formisano. Such partisan identifications did persist, even though employed disparagingly by political opponents.

${ }^{45}$ Ibid. The comment about "roasted oxen, coon skins," etc. is a reference to the Whig "log cabin" campaign of 1840.

${ }^{46}$ Richard Smith Coxe, Address on the Life and Character of General William Henry Harrison (Washington: Peter Force, 1841), 35. This publication sheds further light on Coxe's adherence to Whig thought on the role of the executive branch and the Whig concern with the excessive exercise of executive power, especially by Andrew Jackson. Howe, Political Culture, 92.
} 
nation at this unexpected issue was as universal as it was expressive." To Coxe, William Henry Harrison was an "accomplished statesman" and a "disinterested patriot." Coxe implicitly struck a contrast with Andrew Jackson, pointing to "the arts of a demagogue" and the "machinations of the incendiary seducing and deceiving the public." Though both men came to the White House because of their military records, Harrison came as the servant of the Constitution and its principles, Jackson by exploiting public unrest and seeking to rouse public resentment. ${ }^{47}$

Coxe based his support for both Clay and Harrison on their adherence to Whig principles. Although Coxe had taken clear exception to Clay's favorable attitude toward Latin American independence, other issues overrode this difference of opinion. Coxe's support for internal improvements, coupled with his concern about Jackson's excessive use of executive power, particularly the veto, outweighed differences of opinion on lesser issues, as made manifest in the contrasts Coxe drew between Jackson and both Whig candidates for the presidency.

\section{Coxe and Mexico}

After the short-lived Harrison administration, Coxe again focused on his legal career. The 1840s brought to the fore conflict between the United States and Mexico, which had achieved its independence from Spain in 1822. Unlike many Whigs, Coxe tacitly supported hostilities against Mexico, but he rationalized this support on Whig principles, rather than "Manifest Destiny," the expansion of slave territory, or other arguments set forth by the Polk administration and its allies. Two significant issues had clouded relations between Washington and Mexico City. First, Texas had secured its independence from Mexico in 1836, largely by the efforts of colonists from the United States. Second, American businesspeople had numerous claims because of alleged depredations by Mexican military officers, government officials, and others regarding the seizure, confiscation, and destruction of American property. After Mexico gained its

${ }^{47}$ Ibid., 37-38. 
independence, Americans began business ventures in that new republic, but instability in Mexico disrupted many of those ventures, resulting in losses for the investors.

As a Washington attorney, Coxe represented American investors seeking to recover those losses, knowing that his work had political implications. He brought the matter to the attention of the House of Representatives in 1841, pointing out that the Mexican government had not made good on its commitments to pay the awards as determined by a joint commission of the two countries. He argued that without the "aid and cooperation of their own government," the claimants could not obtain satisfaction. He called for an act of Congress to "apply now in behalf of the claimants the same measures of relief and aid which that act provides the claimants at the close of the convention," a reference to the provisions of the United States-Mexico convention of 1839. Otherwise, the Mexican treasury notes used to pay the claims might depreciate, causing further loss for the claimants. ${ }^{48}$

Coxe put this activity in the context of attacks on U.S. investors in Mexico. In 1846, Coxe published a pamphlet chronicling the usually unsuccessful efforts by Americans to recover their losses; 1846 was also the year that the United States went to war with the Mexican republic. Coxe, although not directly supporting a declaration of war in his pamphlet, laid out a number of valid American grievances and suggested that the United States government had not wholeheartedly supported its allegedly abused citizens in Mexico. He further hinted that a less restrained approach was required to force the Mexican government to meet its obligations, refuting the sentiments of many opponents of war. ${ }^{49}$

Coxe first refuted assertions that Texas had no legitimate grounds for declaring its independence. Coxe argued that the abrogation of the constitution of the United Mexican States,

\footnotetext{
48 "Memorial of the Claims on Mexico," Document 51, House of Representatives, 27th Congress, 1st Session, 1841. ${ }^{49}$ Richard Smith Coxe, Review of the Relations between the United States and Mexico and the Claims of Citizens of the United States Against Mexico (New York: Wilson and Company, 1846).
} 
adopted in 1829, terminated whatever connection Texas had to the Mexican union. Since it was not part of the Viceroyalty of New Spain, Texas was never formally an integral part of Mexico. Nothing "qualified or limited the extent of her [Texas's] sovereign rights." The constitution of 1829 was "overturned" by the revolution of $1834-1835$ in which Santa Anna overthrew the constitutional government and established a military dictatorship. To that military regime, Texans had no obligation. ${ }^{50}$

Texans could thus legally justify the establishment of their independent republic. The Mexican constitution to which it had acceded was no longer operative, and Texans were not bound to Santa Anna's military government. His authority was not legitimate. Coxe compared the actions of Texas to the American protest against unconstitutional, thus illegitimate, actions of the British Parliament between 1774 and 1776. Once independent, Texas held responsibility for its own destiny. Its government chose to become a state of the United States of America. Since it was the "right of every nation to govern itself in its own way," Mexico could not legitimately challenge or question this decision. ${ }^{51}$

Coxe did not trumpet the idea of "Manifest Destiny," nor did he mention President Polk's assertion that United States troops were fired upon on their own soil. Instead, Coxe's main concern remained the refusal of the Mexican government to pay what he regarded as the legitimate claims of American citizens against that government. Coxe pointed out that every American president since Andrew Jackson had attempted to amicably resolve this matter. Despite his overall unfavorable assessment of Andrew Jackson, he also pointed to Jackson's

\footnotetext{
${ }^{50}$ Ibid., 13-20.
}

${ }^{51}$ Ibid., 21-27. 
efforts to resolve a similar matter with France, arguing that Jackson's firmness had brought about a "manly and honorable" response from Paris. ${ }^{52}$

Domestic politics, according to Coxe, only clouded the issue. The controversy over the annexation of Texas was "employed to swell the notes of party discord." Well-meaning Americans, mainly Coxe's fellow Whigs, "portrayed [Mexico] as an innocent and unoffending party." Coxe also pointed out that the United States initially viewed Mexico as a sister republic, and Washington sought to build trade and economic relations to benefit American investors and to develop Mexico's economy. When such efforts went awry, the United States declined offers by the British and French governments to jointly enforce claims against Mexico. The result was that United States citizens were "plundered, imprisoned, and murdered." Mexican authorities, legitimate and otherwise, embarked on a "new career of cruelty and injustice."

Coxe then set forth a detailed analysis of the efforts to adjudicate American claims against Mexico, going back to President Jackson's message to Congress on February 6, 1837, in which Old Hickory expressed his disappointment that an "amicable adjustment" did not appear possible. Jackson's successor, Martin Van Buren, met with similar rebuffs and even urged “any mode of redress known to the law of nations." Actual injury to American citizens accompanied a failure to pay for monetary damages. The Mexican government did not even permit the American consul in Mexico to visit injured Americans. There was "no proof of a desire on the part of the Mexican government to repair any injury or satisfy honor." 54

After much foot-dragging, the two governments signed an "informal memorandum" on August 29, 1838, followed by a formal convention on September 10 of the same year. Mexico, however, did not ratify the convention within the prescribed five months. Another effort

\footnotetext{
${ }^{52}$ Ibid., 38-44.

${ }_{53}^{53}$ Ibid., 44-51.

${ }^{54}$ Ibid., 52-57.
} 
followed this one when a new convention was signed on April 11, 1839, allowing a 12-month deadline for ratification. The two governments did not exchange ratifications until April 8, 1840, a mere three days before the agreed-upon deadline. ${ }^{55}$

Supposedly, this convention opened a "new chapter" in relations between the two nations. The convention mandated that commissioners from both countries adjudicate disputes, with the King of Prussia serving as the umpire. After ratification, Coxe claimed that the Mexican commissioner deliberately withheld or distorted evidence, and delayed proceedings so that work could not be completed within the required 18-month time frame. The Mexican commissioners simply did not allow an objective examination of the claims, not even permitting the introduction of supporting evidence. ${ }^{56}$

Coxe's pamphlet went on and on, raising specific examples of injustices to American claimants. He concluded that the Mexican government was the "spoliator," offering four points to back up this conclusion. First, Mexico or individual Mexicans had committed the "original wrong." Second, the Mexican government had withheld crucial evidence to support American claimants. Third, the Mexican commissioners had introduced false testimony. Finally, he accused that government of "appropriating to herself the very evidence which had been produced to establish her responsibility." 57

Without endorsing a declaration of war on Mexico, Coxe did intimate that more forceful action on the part of the United States government could produce results. He pointed out that diplomacy had failed, and that the United States government must more effectively and forcefully back up the claims of its citizens. He also pointed out that other governments,

\footnotetext{
${ }^{55}$ Ibid., 54-61.

${ }^{56}$ Ibid., 62-67.

${ }^{57}$ Ibid., 120.
} 
especially the French, had achieved results with a mere show of military force without an actual declaration of war. Clearly, Coxe believed that events justified at least that much of a response. ${ }^{58}$ Indeed, Coxe sought to distance himself from the politics of the Mexican War, but, at the same time, he vigorously defended the claimants. In 1847, Coxe refuted remarks by Congressman John S. Pendleton, a Virginia Whig, who politically connected the claimants with the Polk administration in a speech delivered in Congress on February 22, 1847. Coxe decried assertions that the "private interests of individual citizens become complicated and involved with great questions of national or even party policy." He hoped that valid claims of Americans would not become "introduced into a discussion, the professed object of which was to assail the present Executive of the nation," James K. Polk. ${ }^{59}$

Coxe's response to Pendleton made two key points. First, he denied any political motivation. Second, he argued that the United States was obligated to protect its citizens not only on the high seas, but wherever they faced harassment or intimidation. Polk's position on this matter did not differ from that of his predecessors: Jackson, Van Buren, and Tyler. Coxe pointed out that the claimants had to "assume the attitude of obsequious supplicants seeking favors," not

\footnotetext{
${ }^{58}$ Coxe's arguments reflect the historiographical debate over the causes of the war between the United States and Mexico. If Coxe supported the declaration of war, he did so largely on the basis of claims by American interests against the Mexican government and Mexican citizens. Historian Peter M. Jones argued that although claims were an "important issue," that issue was not sufficient "in and of itself" to go to war. Injection of the issue of Texas into the debate tipped the scales in Washington according to Jones. Norman Graebner sees the issue as largely partisan. Claims by interests with Whig connections may have persuaded some Whigs in Congress and in positions of influence, such as Coxe, to support the Democratic Polk administration, thus qualifying Graebner's argument that support was "largely partisan." See Jones, "American Claims and the Mexican War" in Journal of the Early Republic 12:2 (Summer 1992), 213-249 and Norman A. Graebner, "The Mexican War: A Study in Causation" in The Pacific Historical Review 49:3 (August 1980), 405-426. Piero Gleijeses suggests that "flaccidity" characterized Whig politicians before the actual declaration of war, a "toothless opposition." Whig opposition to the Polk administration became more intense only after United States forces advanced deep into Mexican territory. Only then did most Whigs make issues such as the expansion of slavery, and the morality of a war of conquest, matters of concern. Thus, Coxe did not need to overly concern himself with offending his fellow Whigs. See Gleijeses, "A Brush with Mexico" in Diplomatic History 29:2 (April 2005), 223-254. In the end, the declaration of war passed both houses of Congress by overwhelming bipartisan majorities.

${ }^{59}$ Richard Smith Coxe, "Letter to the Honorable John S. Pendleton Containing Remarks up so much of his Speech Delivered in the House of Representatives as Concerns the Claims of Citizens of the United States upon Mexico" (Washington: Davis and Drew, 1847), 3-4.
} 
"injured parties demanding rights," which they in fact were. Pendleton had brought the claimants into a political battle when the claimants themselves had "no political concerns."

Pendleton and Coxe agreed on most questions regarding the obligation of the United States government to protect its citizens abroad. But Coxe asserted that Pendleton limited support for claims to "the single case of citizens pursuing lawful commerce under the protection of their flag," presumably not to acts of violence in Mexico itself. That right was also protected both by treaty and by international law. Coxe admitted a personal interest; some of the claimants were his own clients, but none of those cases were "outside the foundation of public law." None engaged in illegal employment, but their affairs were sanctioned as legitimate by treaties and by the law of nations. ${ }^{61}$

Even in 1855 , long after the war ended, Coxe was still seeking to recover claims against Mexico. On February 20 of that year, a report to the House Judiciary Committee noted unresolved claims involving the Union Land Company dating back to the 1820s. That company had purchased land in Mexico for colonization and improvement by constructing mills and farming communities. After beginning the colonization and development process, the company claimed that local government officials had harassed the colonists, seized their property, and even imprisoned persons whose safety the Mexican government had guaranteed. The committee itself recommended referral of the matter to the Circuit Court for the District of Columbia, noting that the questions involved were of a "judicial nature." 62

\section{The Slave Trade}

\footnotetext{
${ }^{60}$ Ibid., 4-7.

61 Ibid., 10-13.

${ }^{62}$ Report of the Committee on the Judiciary, House of Representatives, 33rd Congress, 1st Session, February 20 , 1855 .
} 
Coxe then shifted his attention to another aspect of international maritime law, regulation of the "nefarious," in his words, slave trade, an issue of concern to many "Conscience Whigs." The major European powers, Britain and France, had abolished slavery in 1833 and 1848, respectively. Slavery, however, continued to thrive not only in the southern United States, but also in Brazil and the Spanish colonies of Cuba and Puerto Rico. The British, more than anyone else, took a proactive role in seeking to suppress the illicit slave trade. At times, the means by which the British carried out their efforts to suppress the slave trade posed a challenge to the rights of American vessels off the African coast.

Coxe sought to defend American sovereignty on the high seas, while at the same time not relaxing efforts to suppress the slave trade. In 1858, Coxe published The Present State of the African Slave Trade, in which he reviewed the history of British and American policies on the subject. Coxe argued that the Royal Navy had exceeded restrictions imposed by international law, especially in its stopping and seizure of American vessels. But he first reviewed historical circumstances of the slave trade, going back into the colonial era of United States history, pointing out that London had rebuffed efforts by several colonial governments to ban the importation of enslaved people before 1776. He also pointed out that the Confederation Congress had banned slavery in the old Northwest, and the United States banned importation of enslaved people into the Louisiana territory, purchased from France in 1803, and banned it completely, in all places, in $1808 .^{63}$

Coxe also pointed to the long struggle in Britain to end the slave trade after its rebuff of efforts by some of the colonies to do that before 1776. William Wilberforce first introduced a bill for that purpose in the House of Commons in 1787. By 1791, he had gained the support of Edmund Burke, Charles Fox, and William Pitt the Younger, but even their combined efforts

\footnotetext{
${ }^{63}$ Richard Smith Coxe, The Present State of the African Slave Trade (Washington: L. Towers, 1858), 1-10.
} 
were "all in vain." After the ban did take effect in 1807, Coxe asserted that the British government exaggerated its role in ending the slave trade. In 1818, the Foreign Secretary, Lord Castlereagh, charged that most of the illicit trade was conducted in American-built vessels, a charge with "much foundation" but also with "much exaggeration.",64

Coxe's main concern was that the Royal Navy had exceeded its rights under international law. British actions were a "deviation from the existing usage of the English and American navies" and a violation of the law of nations. Although the Webster-Ashburton Treaty of 1842 set up procedures for the suppression of the slave trade, British captains violated the spirit and specific terms of that treaty. Coxe advocated the establishment of a joint Anglo-American commission to set up a means for both countries to jointly suppress the "nefarious traffic" and, at the same time, protect American sovereignty. ${ }^{65}$

\section{Conclusion}

Richard Smith Coxe's career spanned more than 50 years of United States history. Rather than following in his father's footsteps and remaining in Burlington County, Richard Smith Coxe recognized that New Jersey politics did not offer a promising future for a young Federalist. He thus decided to move to Washington, DC, where he became a prominent attorney, specializing in cases involving maritime and international law. His friendship with the powerful New Jersey politician Samuel L. Southard enabled him to serve as judge advocate of the navy and gain access to the highest counsels in the administrations of James Monroe and John Quincy Adams. Working with Southard, he acted to influence New Jersey politics in the presidential campaign of 1824. After Southard's departure, he supported the emergent Whig Party, particularly Henry

\footnotetext{
${ }^{64}$ Ibid., 11-12. For a discussion of such unsuccessful efforts to ban the importation of slaves into New Jersey, see Bruce A. Bendler, "'Love for Justice and a Wish to Promote It': The Politics of Slavery in New Jersey 1770-1775" in New Jersey Studies 3:1 (2017), 23-47.

${ }^{65}$ Ibid., 14, 27, 31.
} 
Clay, but he no longer paid much attention to his home state. Though not divorcing himself from politics, Coxe focused on international affairs related to his law practice, such as the David Porter case, the claims of Americans in Mexico, and the slave trade.

Despite the diverse nature of his career, certain common threads stand out in Coxe's work. He accepted the worldview of his family-respect for property and the sanctity of contracts. Many of his legal cases involved the protection of property rights, whether those of Americans who suffered losses in the political caldron of Mexico or American interests on the high seas. Politically, when the Second Party System replaced the first, Coxe shifted his allegiance to the Whig Party, generally more favorable to such conceptions of property and contracts than the Jacksonian Democrats. Unlike some Whigs, Coxe evinced some sympathy for the declaration of war against Mexico in 1846, but not for the same reasons set forth by President Polk and his Democratic allies. Coxe's advocacy of harsh measures against Mexico stemmed from his disgust at that nation's spoliation of American entrepreneurs in that country, not from devotion to Manifest Destiny or advocacy of the expansion of slavery. Even if he strayed from party orthodoxy from time to time, Richard Smith Coxe generally adhered to the values of an American Federalist and Whig who adapted those values to a changing domestic political environment and a growing American role overseas.

Bruce A. Bendler received his PhD in history from the University of Delaware in 2000. He is currently an adjunct professor of history at the University of Delaware. He specializes in late colonial and early republican United States history, focusing on the mid-Atlantic states. He is a frequent contributor to Delaware History and New Jersey Studies. His study of efforts by Quakers in Salem County to end enslavement within their body was published in James 
Gigantino, ed., The American Revolution in New Jersey: Where the Battlefront Meets the Home Front (New Brunswick, 2015). 